綜説

\title{
凍結真空乾燥した食品について
}

\author{
木村進 ${ }^{*}$ \\ （昭和 35 年11月15日受理）
}

\section{Foods Processed by Freeze-drying}

\section{Susumu KIMURA}

(Food Research Institute, Department of Agriculture and Forestry)

われわれが食品を加工、貯蔵するにあたって、第一に 考慮しなけ秃ばならぬ点は、いかに新鮮物にまたは加工 前の状態近いものにとどめるかということである。従 来この考えかたから缶瓶詰、冷蔵、冷凍など食品保蔵の 加工法が研究され、加工食品として市販されてきたので ある。

第 2 次大戦後の混乱期以後、われわれの生活様式注 とともに合理化の方向にむかっ進んでいる。食生活の面 において、食糧構成およびその形態において相当の変革 があらわ秃てきている。

近年注缶瓶詰、冷凍食品、水産練製品などの加工食品の 生産および消費量は急激な増加を示しているが、このこ とは、そ北らの加工食品が貯蔵、輸送に便利であること、 食用に供するばあいに煩雑な調理と時間を要しないこと 食事内容を “豊がにすることなどの特徵をるっている ことによると考光てよいであろう。ま、このととは従来 一般の食事においてはあまり重きを置かれてなかった乾 燥食品も、食生活の合理化の観点から再認識される気運 になってきている。粉末スープ、インスタント・コーヒ 一などの消費の増加はその一端を示すものといいよう。

\section{食品の凍結真空乾燥の意義}

食品の乾燥には 2 つ意味が含まれている。ひとつは 食品を乾燥することによって、乾燥前の食品本来の品質 とは異るるのとする。すなわら、色、味、芳香、歯切れ などまったく異ったものにかえてしまい、新しい食品を つくりだすことであり、ひとつは食品を乾燥することに よって、その食品本来の特性をそのまま保持し、貯蔵輸 送性を賦与することである。いずれも水分の多い食品か ら水を除去し貯蔵輸送性を与えることに相異はないが、 品質面からみたばあいはまったく異ったものである。 従来の乾燥食品法、どちらかといえば前者に属するも

* 農林省食糧研究所
のが多い。たとえば、凍豆腐は水に浸しておいても豆腐に なるものではなく、スルメも同じように生イカにもどる ものではない。干バナナ、干柿、干ブドウ、干シイタケな どすべて水に浸漬しておくことにより、乾燥前の形態ま たは品質にもどるものではない。これら常圧における乾 燥方法によったばあい、乾燥工程中に品質の変化が進み、 乾燥前にはなかった色、芳香、味が生じ、結果としてひ そつの加工品が創造されたことを意味するものである。 したがって、従来の乾燥方法により乾燥さ机、われわれ に親しまれてきたものは、乾燥により品質が悪変せず、 しかも、なにか品質的にタて特性を賦与されたものだけ である。

乾燥食品が貯蔵、輸送に便利であると同時に、食用時 にすみやかに乾燥前の状態に復元 (reconstitution,

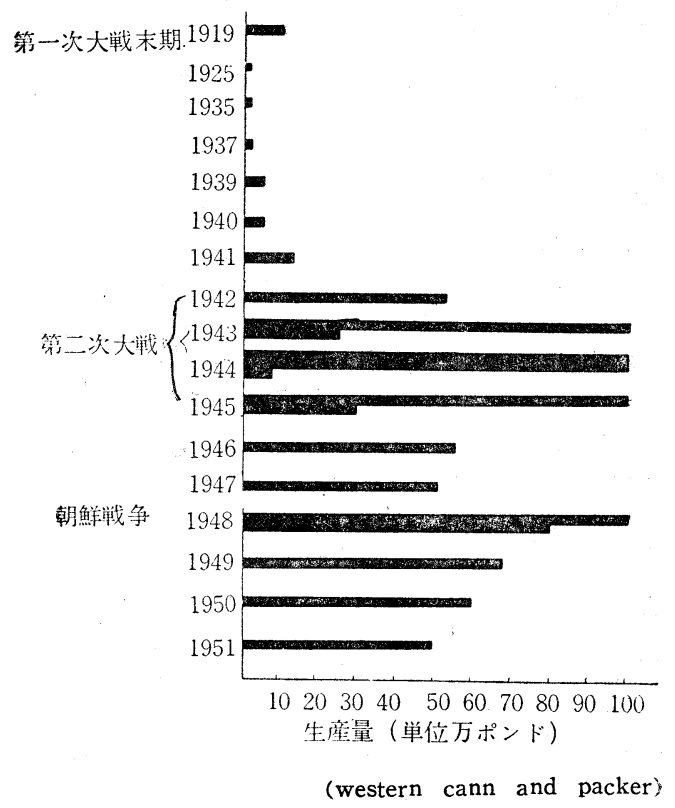

第 1 図 米国における乾燥疏菜の生産量 
rehydration……還元、復水、吸水、もどり、などともい われる)するならば、これは乾燥食品としてもっとも望 ましいものである。

従来の常圧下に和ける乾燥方法では、上述の 2 つの要 求を満足さす乾燥食品はえがたかった。このこと弾戦時 中に各国で多くの食品が乾燥食品として利用されたのに もかかわらず、そのほとんどが戦争終了とともに姿を消 してしまった過去の事実を多てもわかることで亦る。

第 1 図注米国に打ける過去 30 年間の乾燥蔬菜の生産量の グラフであるが、これをみても乾燥食品が戦時中のいわ 浮る救荒備蓄用の加工食品であり、平時の食品になりき っていないことがうかがわれる。ただ1940年代と1950年 代とを比較したばあい、その生産量法約10倍になってい る。このことは乾燥技術の向上と処理方法の向上とによ り、乾燥食品の品質が向上されてきたとと、乾燥食品が 貯蔵、輸送、使用の点で两るという、乾燥食品本来の特 性が再認識されてきたととをものがたっている。

従来の乾燥食品がいくつかのものを除いて、日常の食 生活にとり入れられなかったのは、つぎのような品質面 に大きな原因がある。すなわら、従来の常圧下に打沙る 乾燥方法では、被乾燥食品は長時間高温に保たれ、内部 水分の拡散と表面からの蒸発を繰返し乾燥が進められる ため、その間に揮発性成分 (芳香) 注晩散安た注分解、 重合してその特性を失ってしまう。また、高温已空気中の 酸素により、天然色素は酸化、分解退色乙、糖とアミノ 酸との反応および糖、ビタミンCその他の成分の酸化分 解による褐变反応が進み、その食品本来の色調が失われ る。蛋白質、ペクチンその他のコロイド物質は凝固結合 乙素面硬化 (case hardening) をおこし、物理的に弾 性、強度の変化が和こる。このような変性がすすむる、 水分の拡散および蒸発抵抗が大きくなり、結果として低 水分の製品をうることがむずかしく、したがって、その 乾燥製品を貯蔵したばあいる、水分の介在により变質が すすみやすいわけである。このような乾燥食品は水また は湯に浸漬しても乾燥前の食品の状態にもどることは困 難で、復元にも長い時間がかかるわけである。

これら従来の乾燥食品とおも括きを異にし、一般の食 生活にとり入れらるべき乾燥食品はどのような品質と特 徵を具備すべきであろうか。端的に表現するならば、食 用時に水また湯をそそぐなり、浸漬す秃ば、ただちに 元の乾燥前の食品に復元し、色、芳香、味、歯切れ、栄養 価ともに乾燥前の食品之同様のものとなるようなもので なけ机ばならない。たと光ば、乾燥カキ(貝) を酢に浸せ ばただちに』酢ガギになり、乾燥苜を水に落せばただ ちに美麗なそしてかおり高い生㭧となり、乾燥味噌汁粉 末に湯をそそげば瞬間にかおり高い味噌汁になるといっ
たようなものが望ましいわけである。

このような乾燥食品製造の可能なととは、すでに第1 次大戦中に医療薬剤関係で証明された。すなわち、ペニ シリン、輸血用の乾燥血漿を可能にし、幾多の生命を救 口た方法が凍結乾燥であった。しかも食品の乾燥に凍結 乾燥を利用しようとする研究は Flosdorf らによって 1943年頃から注じめられ、その実用化の研究注1950年以 降になって各国で洼じめられるようになった。現在は欧 米各国ともに乾燥食品の研究者の一致した意見としては 凍結乾燥が食品の乾燥方法として理想的なものであると いうことである。なた、最近は欧米において凍結乾燥し た乾燥食品が市販される段階となっている。

\section{食品の嚓結乾燥}

常压下での食品の乾燥は、高温低湿の条件下で、食品 中の水分の内部拡散と表面蒸発とを繰返させ水分の除去 艺行うものであり、これに対し真空下の乾燥は水分の直 接の蒸発または水の蒸発 (昇華) によるもので、真空度 の調節により希望する低温度で乾燥を進行させることが できる。

真空乾燥も凍結乾燥と同様、真空中で乾燥をすすめる ことにおいて本質的な相違はない。ただ凍結乾燥は乾燥 にうつすまでに速かに変質してしまう食品、または真空 中で直接乾燥するばあい内部水分の急激な蒸発により、 被乾燥食品の組織をたは形態の破壊がおこる危険のある

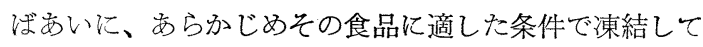
から、真空中で乾燥するものである。たとえ泣、カキ(貝) など注凍結せずに直接高真空中の乾燥室に入れたばあ い、急激に組織中の水分は蒸発し、乾燥态犰たものはカ キの形態をとどめないものとなってしまう。また量的に 処理する場合、乾燥まで生のままで放置したばあいは鮮 度泜下し、貯蔵中に乾燥製品の品質に対して悪影響を 与える。このような形態、品質の変化を防止し、生のカ キの形態のままで乾燥品とするためには、どうしても凍 結して和く必要がある。逆に、果汁、コーヒ一、酱油、味 噲のように液状、ペース状のものを粉末状態に安で乾燥 するばあいは、その形態がその食品の品質を左右するも のでないので、しいて凍結乾燥の必要はなく、たんに真 空中で乾燥すれば目的の製品はえられる。

このような意味から、広義の真空乾燥を狭義に真空乾 燥と凍結乾燥とにわけて考えるべきであろう。

\section{1. 乾燥装置}

食品を凍結乾燥する場合に必要な装置を示すと第 2 図 のごとくである。装置のおもな部分は乾燥室、凝結機、 真空装置、加熱装置である。もちろん乾燥条件の決定、 品質管理上から真空計、温度計およびその自動制御、自 

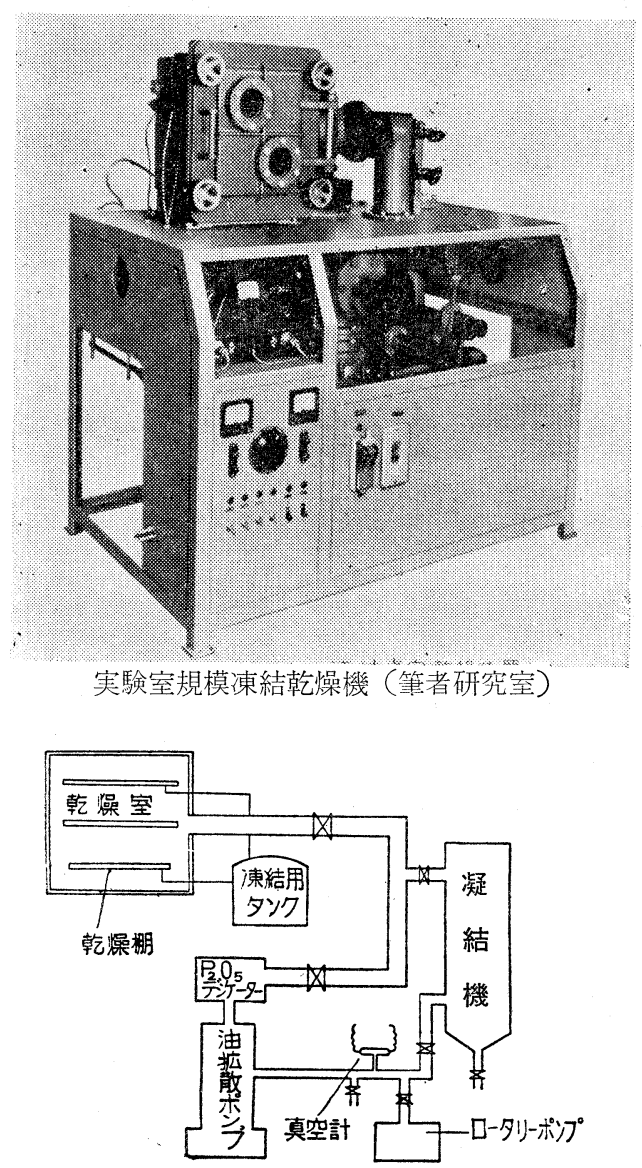

第 2 図涷 結乾燥装置

動記録計が必要で㠰る。

乾燥室には被乾燥食品を乗せる乾燥板を沶く棚が女 る。この棚とのものが昇華速進（乾燥時間の短縮）のた めの加熱を行う棚になっているものが多い。

凍結乾燥においては水蒸気の排除はおもに凝結機によ って行われる。すなわ方、乾燥される食品の飽和水蒸気 圧と凝結機内の水蒸気圧との差が脱水の原動力となる。 凝結機は小規模のばあい、五酸化燐のような吸湿剂、ド ライアイスのような寒剤などが使用出来るが、実用規模 の装置には冷凍機が使用される。いずれのばあいも凝結 機の凝結表面に均一に水蒸気が凝結しうるように設計さ れるばならない。

食品の凍結乾燥に必要な真空度は $1.0 \sim 0.01 \mathrm{mmHg}$ 程度が要求される。ゆえ潽通ロータリ一真空ポンプが 使用される。その排気量は装置全体からの洩りの量、装 置内の容器その他から出るガスの量、被乾燥食品に含ま れる非㠜縮性なぞの全量を一定時間内に排除乙得るもの であればよい。たとえば装置内を $0.1 \mathrm{mmHg}$ まで 5 分
間で真空にするためには、安全率をみて、その装置容積 の 4 倍の容積を 1 分間に排気するものであればよい。大 規模装置にはスチームェジェクターなども使用される。 $10^{-3} \mathrm{mmHg}$ 以上の高真空をうるためには、油拡散ポン プが使用されるが、食品の場合例外をのぞき $10^{-3} \mathrm{~mm}$ $\mathrm{Hg}$ 以上の高真空は㐫まり必要としない。

乾燥速進のために、すなわち、昇華潜熱の補給の意味 で加熱するために、電熱、蒸気、熱溶媒を熱源として使 用する。加熱、熱源のいずれをとわず有効に加熱するた めには、加熱方法が問題である。乾燥板にのせた被乾燥 食品を単に加熱棚から（下部からのみ）加熱する単一加 熱 (single plate heating) では、凍結乾燥において昇 華は外層から内層に向って進むことから有効ではない。 ゆ光に被乾燥食品の両面から加熱 (double contact plate heating 複式加熱) する方法を採用すれば乾燥は均一に 進行する。被乾燥食品の厚みのうすいものに対しては片 面は赤外線ランプの輻射熱を利用しても有効である。さ らに複式加熱において乾燥板に多数の鋲をつけこれに被 乾燥食品をはさ久、熱伝導面積を拡大寸ればさらに乾燥 時間注短縮される。(double spiked plate heating) と れら乾燥板を使用したばあいの乾燥時間を比較すると 第3図のごとくである。このほか加熱を有効に行うため に注周波数 $60 \mathrm{Mc}$. $2400 \mathrm{Mc}$. 程度の micro wave を使 用することもある。この micro wave による誘電加熱の ばあいは乾燥時間は単一加熱の1午程度に 短縮可能であ る。ただ micro wave の発振装置、温度調節などの点、経 済的、技術的にまだ難点があり研究段階を出ていない。

食品の凍結乾燥においては真空度は $1.0 \sim 0.01 \mathrm{mmHg}$ 程度が要求される。そのため乾燥中の真空度の測定には 10〜0.001 $\mathrm{mmHg}$ 程度の範囲を測定し得れば十分であ る。したがって、使用する真空計は、ガイスラー管、水銀 または油マノメーター、マクレオード真空計、ピラニゲ 一シ、熱電対真空計が適当といえよう。実用規模の装置 と用しては、操作が簡易で、堅牟なととが要求される。

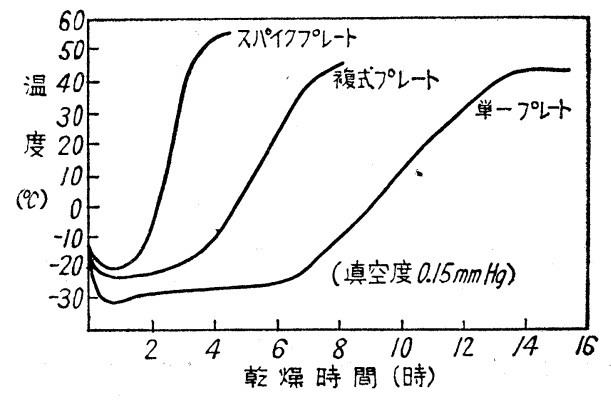

第 3 図 各加熱方式による乾燥速度の比較 ( $3 / 4$ インチ生牛肉) 
真空度の測定と温度測定は乾燥管埋上重要なととで㐫 る。一般に温度測定は熱電対温度計が使用されるが、感 度、精度の点からはサーミスター温度計がすぐれてい る。乾燥にあたって温度管理を正しく行うためには、被 乾燥食品の表面および中心温度、乾燥板および加熱板温 度、乾燥室から排気系に通ずるパイプの間の温度、凝結 機温度など個々に測定し得るように温度計の配置を行う べきである。また、これらの各部分の温度測定のために感 熱部を平板、針状などの形態とし、正確な測定に適した 形状強度にする必要がある。

\section{2. 乾 燥}

凍結乾燥においては乾燥中つね被乾燥食品法低温度 に保たれているので（第 5 図参照）、乾燥中におこる熱 変性および、酸素、䤉素による化学的変性はほとえど無 視してもよい。しかし、乾燥開始前に抗酸化処理、酵素 の不活性化などの变色、退色、变質に対する前処理を行 っておかないと、乾燥製品を貯蔵中にある程度の変色、 off-flavor、脂肪の酸化による悪臭などの変化がま好か ず、復元、食用に供する場合に乾燥前とは品質的飞低下 してしまうことも生ずる。

これらのことから、被乾懆食品の成分組織に応じた前 処理を行う必要がある。たとえば、ホウレンン一、セロリ 一、キャベッなど有色蔬菜類にたいしては 95〜100 ${ }^{\circ} \mathrm{C}$ の熱水中で 1 ～ 3 分程度のブランチングを行うことによ り貯蔵中の褐变を防止し得る。蓮根、ゴボウなど処理中 に黒変など変色の速かなものにたいしては、亜硫酸塩 類、食塩溶液中で軽くブランチングすることにより処理 中の変色、乾燥後の変色も防止乙得る。リンゴその他の 酸化酵素の強い果実にたいしては、亜硫酸塩類、ビタミ ソC、その他の還元性物質、有機酸、食塩溶液に一定時間

第 1 表 乾燥に適する濃度

\begin{tabular}{|c|c|c|c|c|c|}
\hline & & 食 & 品 & 名 & 全固形量 (\%) \\
\hline \multirow[t]{2}{*}{ 果 } & 汁 & $\begin{array}{l}\text { ブ } \\
\text { 柑 } \\
\text { 原 } \\
\text { s }\end{array}$ & 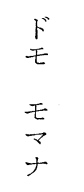 & 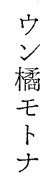 & $\begin{array}{l}50 \sim 55 \\
40 \sim 45 \\
50 \sim 60 \\
60 \sim 70 \\
25 \sim 35 \\
20\end{array}$ \\
\hline & & & 一茶 & - & $\begin{array}{l}40 \sim 50 \\
30 \sim 35\end{array}$ \\
\hline 鶏 & 卵 & $\begin{array}{l}\text { 全 } \\
\text { 卿 }\end{array}$ & & $\begin{array}{l}\text { 㧮 } \\
\text { 黄 } \\
\text { 白 }\end{array}$ & $\begin{array}{l}28 \\
45 \\
10\end{array}$ \\
\hline 4 & 乳 & $\begin{array}{l}\text { 全 } \\
\text { 脱 }\end{array}$ & 脂 & $\begin{array}{l}\text { 乳 } \\
\text { 乳 }\end{array}$ & $\begin{array}{l}30 \sim 35 \\
35 \sim 40\end{array}$ \\
\hline
\end{tabular}

浸漬することにより䤉素作用による褐変を防止すること が出来る。トマト、人㣊、桃など脂溶性の色菒カロチ ノイドを含むものまたは、牛肉、豚肉、魚介類など脂唹の 多いものは、乾燥後に空気中の酸素による酸化が進み、 結果として前者は退色して特有の美麗な色浪消失し、後 者はいわゆる』油やげが進み、着色が進久、off-flavor も起る。これらの食品にたいしては乾燥前に抗酸化剂の 添加、滲透写行う必要がある。

果汁、蔬菜汁、牛乳、コーヒ一、茶など水分分量 90 \%以上である。これらのものを直接無水物に近い状態 で乾燥することは、乾燥効率、施設の面から非常に不利 な場合が多い、このととからこのような液体の水分の多 い食品はあらかじめ、真空浱縮また法凍結濃縮により 第 1 表に示す程度の濃縮液としてから、乾燥に移すべき である。

凍結乾燥に打いては、乾燥前の凍結条件法品質左右 するひとつの因子となる。すなわ台、食品定凍結するこ とにより食品の組織中の水が氷結する場合に、その条件 によって氷の結晶の状態すなわ台、氷の結晶の大きさ怘 異り、結果として、食品の物理性に影響することが多い わけである。たと党ば、第 4 図の鷄肉の凍結切片の顕微鏡 写真にみられるように $-10^{\circ} \mathrm{C} て ゙$ て涷結した場合と一60〜 $-70^{\circ} \mathrm{C}$ で凍結した場合とで注、形成さ机た氷の結晶の 大きさが異る。 $-10^{\circ} \mathrm{C}$ の方沈大きな水の結晶のため悢 織がバラバラに破壞された状態沂くなっていること只 わかる。このようになったものは、乾燥したものを復元 しても、食用に供した場合に texture 寸なわ台《㐘切秃” がなど物理性不自然なものとなる。このことから凍結仗 冷谏食品之同様考光るべきであるう。すなわち一 $30^{\circ}$ 〜

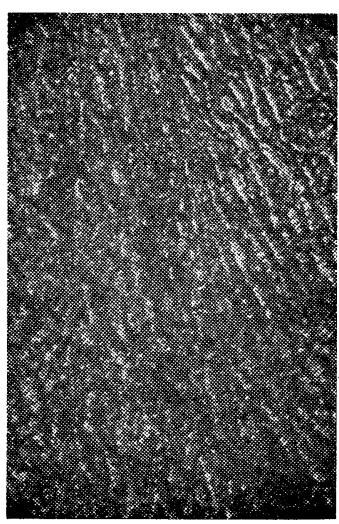

-60 - $70^{\circ} \mathrm{C}$ で涷結し たもの

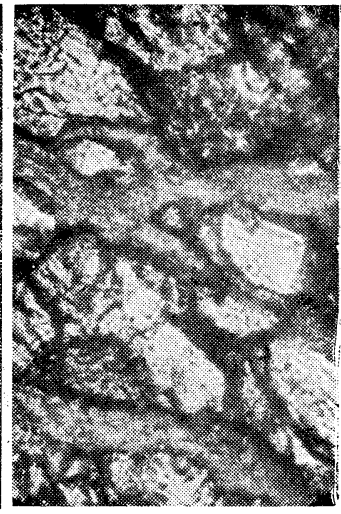

$-10^{\circ} \mathrm{Cで}$ 涷結したすの 粗い大きな水の結晶が形 成している。（白く光っ ている部分)
第 4 図凍結生鵎肉の顕微鏡军真 
$-40^{\circ} \mathrm{C}$ 程度の温度で急速に凍結すべきで、理想的には double contact plate で急速冷凍が望ましい。

以上のように前処理および凍結されたもの佂真空中 で昇華による乾燥が進められるのであるが、その乾燥の 条件を表示すると第 2 表のごとくである。乾燥中の被乾 燥食品の品温および水分の変化を示すと第 5 図のごとく 乾燥法常に低温で進められ、乾燥の終了は被乾燥食品の 品温と乾燥板温度から見出し得ることがわかる、乾燥速 度は前述したごとく、被乾燥食品の厚み、加熱温度、真

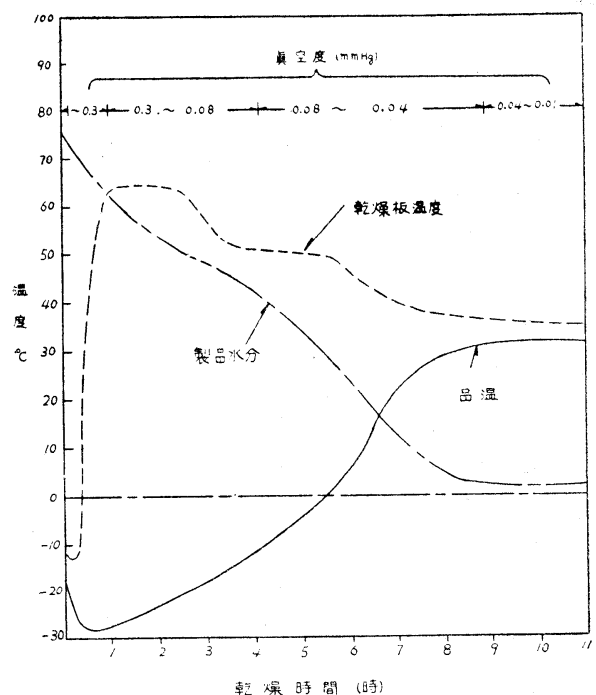

第 5 図力キ (貝) の凍結乾燥中の品温、乾燥 板温度、乾燥室内の真空度扎よび被乾燥物の 水分の変化

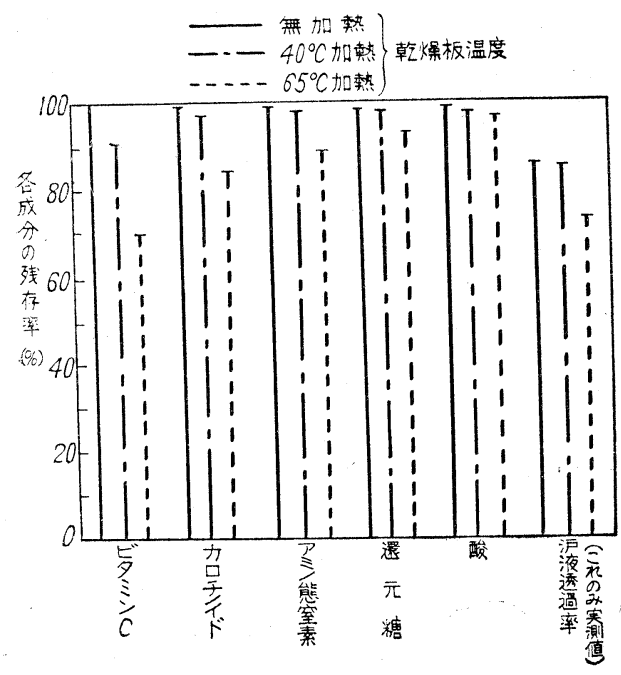

第 6 図トマトペーストの涷結乾燥における加 熱温度と成分变化
空度の三つの因子により決定される。

乾燥中の成分变化注想的条件、すなわち、無加熱て 行った場合には品温は常に低温に保たれるためほとんど 起らない。しかし、実際問題としては乾燥時間を短縮す るために（昇華促進のため）加熱する必要がある。加熱 温度が高い場合、この乾燥法でもある程度の成分变化は 考えられる、その程度を第 6 図に示した。しかし、その 変化嫦压の乾燥方法の变化に比較した場合には無視し 得る程度のものである(第 2 表参照)。

\section{3. 乾燥製品の特徴}

前述の乾燥装置、条件で乾燥した製品は非常に多孔質 な状態に乾燥されるため固形物の収縮はなく、原形をと ぞめた乾燥製品となる、可溶性成分の表面への移動固化 がないため被乾燥食品表面の 2 重 3 重の不滲透性の層の 形成 (case hardening) がない。このため乾燥食品とし

\section{第 2 表 各種食品の凍結乾燥例}

\begin{tabular}{|c|c|c|c|c|}
\hline 食品 名 & $\begin{array}{ll}\text { 厚 } & \text { म } \\
(\mathrm{mm})\end{array}$ & 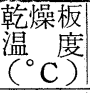 & \begin{tabular}{c|} 
真 空 \\
$(\mathrm{mmHg})$
\end{tabular} & $\begin{array}{l}\text { 乾燥時 } \\
\text { 間 }(h)\end{array}$ \\
\hline 牛肉 (煮熟) & $8 \sim 10$ & 55 & 1 & 6 \\
\hline マグロ（生） & 6 & 40 & 1 & 6 \\
\hline 力 $\neq$ (生) & $10 \sim 15$ & 40 & $0.5 \sim 0.01$ & 14 \\
\hline 力 $=$ (水煮) & $10 \sim 20$ & 40 & $0.5 \sim 0.01$ & 8 \\
\hline ビ(半割水煮) & $8 \sim 10$ & 45 & $0.5 \sim 0.01$ & 6 \\
\hline 白（生） & 5 & 40 & $0.5 \sim 0.01$ & 4 \\
\hline 黄（生） & 5 & 40 & $0.5 \sim 0.01$ & 3 \\
\hline 卵（生） & 5 & 40 & $0.5 \sim 0.01$ & $3 \sim 4$ \\
\hline 桃 (8 当分) & $10 \sim 20$ & 45 & $0.5 \sim 0.01$ & 14 \\
\hline 缶＼cjkstart桃 & $10 \sim 15$ & 45 & $0.5 \sim 0.01$ & 12 \\
\hline バナナ（輪切） & 5 & 45 & $0.5 \sim 0.01$ & 6 \\
\hline トマトジュース & 5 & 50 & $0.5 \sim 0.01$ & $4 \sim 5$ \\
\hline ピーマン（生） & 4 & 50 & 1 & 5 \\
\hline$" \quad$ (ブランチ $)$ & 4 & 50 & 1 & 4 \\
\hline キャベッ & $1 \sim 2$ & 50 & 1 & $2 \sim 3$ \\
\hline タマネギ（輪切） & $3 \sim 4$ & 50 & 1 & 5 \\
\hline 人䓗（輪切） & 4 & 50 & 1 & 5 \\
\hline 八ス（輪切） & 4 & 50 & 1 & 4 \\
\hline 馬 鈴 薯(ブランチ) & 10 & 55 & 1 & 5 \\
\hline ワサビ（輪切） & $2 \sim 3$ & 50 & 1 & 3 \\
\hline ショウガ (輪切) & 2 & 50 & 1 & $3 \sim 4$ \\
\hline マツタケ & 10 & 45 & $0.5 \sim 0.01$ & 5 \\
\hline 正 油 & 3 & 45 & $0.5 \sim 0.01$ & 3 \\
\hline 味＼cjkstart噌 & 4 & 45 & 1 & $4 \sim 5$ \\
\hline 緑 茶(濃厚浸出液) & 4 & 40 & $0.5 \sim 0.01$ & 3 \\
\hline 紅 茶(濃厚浸出液) & 4 & 40 & $0.5 \sim 0.01$ & 3 \\
\hline コーヒー-(濃厚浸出液) & 4 & 40 & $0.5 \sim 0.01$ & 3 \\
\hline ロイヤルゼリー & 4 & 40 & $0.5 \sim 0.01$ & $1 \quad 2 \sim 3$ \\
\hline
\end{tabular}


第3表 各種乾燥法による食品の乾燥条件と品質

\begin{tabular}{|c|c|c|c|c|c|c|c|c|c|}
\hline 名 & 乾 燥 法 & $\mid \begin{array}{c}\text { 乾燥板温度 } \\
\left({ }^{\circ} \mathrm{C}\right)\end{array}$ & 真 (mmHg) & $\begin{array}{c}\text { 乾燥時間 } \\
\text { (時) }\end{array}$ & $\begin{array}{c}\text { 製品の水分 } \\
(\%)\end{array}$ & 外 & 観 & $\begin{array}{l}\text { 組 }{ }^{\text {織 }} \\
\text { case } \\
\text { hardening }\end{array}$ & 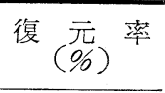 \\
\hline 蒸煮鶏肉 & 真 空 乾 燥 & $\begin{array}{c}70 \sim 73 \\
70 \sim 72 \\
40 \sim 42 \\
40 \sim 42 \\
20\end{array}$ & $\begin{array}{r}175 \\
40 \\
20 \\
0.3 \\
0.2\end{array}$ & $\begin{array}{r}8.5 \\
9.0 \\
10.5 \\
10.5 \\
9.0\end{array}$ & $\begin{array}{r}31.7 \\
24.7 \\
39.2 \\
7.8 \\
32.0\end{array}$ & $\begin{array}{c}\text { 暗 } \\
\text { 暗 } \\
\text { 僅に暗 } \\
\text { 良 } \\
\text { 良 }\end{array}$ & & $\begin{array}{l}++++ \\
++++ \\
++ \\
+ \\
-\end{array}$ & $\begin{array}{l}\left(R_{\text {EGIER }}\right) \\
\quad 30\end{array}$ \\
\hline 生 牛 肉 & $\begin{array}{l}\text { 真 空 乾 燥 } \\
\text { 凍結真空乾燥 }\end{array}$ & $\begin{array}{r}0 \sim 15 \\
35 \sim 45 \\
-15 \sim 40\end{array}$ & $\begin{array}{c}23 \\
23 \\
0.2 \sim 0.1\end{array}$ & $\begin{array}{l}60.0 \\
65.0 \\
24.0\end{array}$ & $\begin{array}{r}20.0 \\
7.5 \\
3.0\end{array}$ & $\begin{array}{l}\text { 暗褐 } \\
\text { 暗褐方 } \\
\text { 淡 }\end{array}$ & $\begin{array}{l}\text { 色 } \\
\text { 色 } \\
\text { 紅 }\end{array}$ & $\begin{array}{l}++ \\
+ \\
+\end{array}$ & $\begin{array}{l}30 \\
80 \sim 90 \\
\left(\mathrm{~T}_{\text {APPEL }}\right)\end{array}$ \\
\hline 生白桃 & $\begin{array}{l}\text { 通風 乾燥 } \\
\text { 涷結真空乾燥 }\end{array}$ & $\begin{array}{r}70 \sim 75 \\
-20 \sim 60\end{array}$ & $\begin{array}{c}360 \\
0.5 \sim 0.005\end{array}$ & $\begin{array}{l}20.0 \\
14.0\end{array}$ & $\begin{array}{c}(7 \sim 8) \\
2.5\end{array}$ & $\begin{array}{l}\text { 暗褐㫐 } \\
\text { 臽 }\end{array}$ & 色 & $\frac{t++}{-}$ & 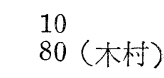 \\
\hline
\end{tabular}

て第一に要求される復元性は非常に高い。食品成分とし て好ましい種々の成分の熱変性がほとんどない。すなわ ち、蛋白質、アミノ酸、天然色素、ビタミンその他コロ イド物質の変化がはい。このことは復元後の色調、味が 䡎燥前と変らないことを意味している。揮発性分の損失 が少いことからその食品本来の芳香も比較安定に保たれ ている、製品の水分は経済的な乾燥条件を与えて乾燥乙 ても、3\%以下の低水分まで容易に乾燥されるために、 常温貯蔵においても品質は非常に安定である。

このように乾燥食品として具備しなければならぬ味、 芳香、色調、品質の安定性、復元性のあらゆる点で満足 すべきものである。製品の一例を示すと第 7 図のごと くである、乾燥マッタケはあつい汁に入れればただちに 秋のかおりがただよい、乾燥菌は水に浸漬するだけで 美麗な色とかおり、味を賞味するととが出来る。同様 に果汁、コーヒー、緑茶、味噌汁、輏油などの乾燥粉末 も水または湯に投入することによってたたちに飲用また

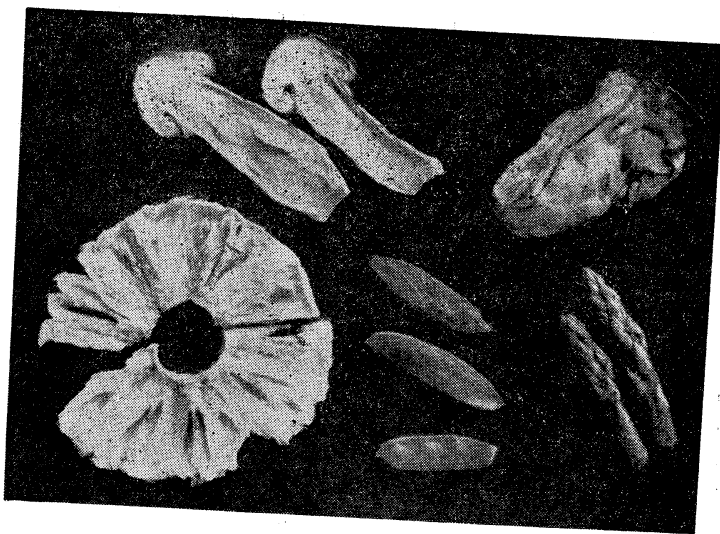

第 7 図凍結乾燥製品

上左 マッタケ 上右 生ガキ(貝)

下左から パインアップル、サャエンドウ、 グリーン、アスパラガス
は使用される状態にもどる。

\section{4. 乾燥製品の包装および貯蔵}

凍結乾燥による製品は以上のごとく品質的に非常にす ぐれたものである、しかし、製品の組織は多孔質であ り、低水分であることふら、吸湿市よび酸化表面積が拡 大されていることを意味している。このことから吸湿に よる形態の取縮、固結、液化などの変化、復元性の低下 が起る。また脂肪の酸化は、油やけ、となってあらわれ 変色、異臭の原因となるし、脂溶性色素カロチノイドは 酸化の結果退色してしまう。

たとえば、凍結乾燥した乾燥 コーヒー粉末、輏油粉 末、果汁粉末などは、室温 $25^{\circ} \mathrm{C}$ 関係湿度 $70 \%$ 程度の条 件に放置された場合、10分以内に $4 \%$ 程度の吸湿率を示 し、粉末特有のサラサラした感じは消失し、30分程度放置 した場合は10\%以上の吸湿量を示し、徐々に表面は液化 の状態となる、このようになったものは、溶解度はもち ろん低下してしまう。苗を凍結乾燥した場合、アントシ アニンによる蒰の特有の美麗な色はそのまま残り、2\% 以下の水分に保てばその色は $1 \sim 2$ 年間 $30^{\circ} \mathrm{C}$ 程度に貯 蔵しても失われずに残存するが、これを関係湿度 $70 \%$ 、 室温 $30^{\circ} \mathrm{C}$ 程度の条件に貯蔵した場合は 2 週間程度でア ントシアニンは分解し葸の特有の色は消失してしまう。

このような吸湿による変性、すなわら、製品の水分含 量の增加によっておこる变化は、水溶性成分の分解、結 合により進毛のであるから、製品を低水分の状態と し、低湿の条件下で検査、充埧、包装すべきであること を示している。凍結乾燥食品のごとく一般に吸湿性の高 い製品の取扱いは関係湿度20\%以下の環境で行うことが 望ましい。

脂肪の酸化の結果は前述のごとく、、油やけ、の状態 となり、色、ニオイ、味は低下し、脂溶性ビタミンは酸 化し栄養面からも品質は低下与る。また、脂溶性の天然 色素であるカロイドは酸化し、トマト、人藝、オレン 
ジ、西瓜などの特有の美麗な色調を失ってしまう。これ らの酸化による乾燥食品の低下は、たんに製品の水分含 量を低下させるだけでは防止は出来ない。こ礼ら酸化防 止の手段として考えられることは、乾燥前に抗酸化剂ま たはそれらと相乗作用を有する添加剤を添加処理し、さ らに包装容器に充填するさいに、真空充㙋を採用すると か、窒素ガス、炭酸ガスなど不活性ガスを容器中の空気 と置換することなどの方法を採用する。

凍結乾燥によった乾燥食品は多孔質であり、さらに低 水分であることから、弾性、強度は他の加工食品とは非 常に異る。凍結乾燥食品のこれらの研究例はほとえどな いが、筆者の測定結果の一部はつぎのごとくであった。 凍結乾燥食品の破砕強度は水分 $1 \%$ 煮熟牛肉乾燥品

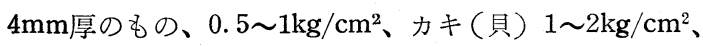
$3 \sim 4 \mathrm{~mm}$ 厚の乾燥バナナ $2 \sim 3 \mathrm{~kg} / \mathrm{cm}^{2}$ 、キャベッ $0.5 \mathrm{~kg}$ $/ \mathrm{cm}^{2}$ 以下であった。こ秃に対しビスケット、4〜 $5 \mathrm{~kg} /$ $\mathrm{cm}^{2}$ 、カワラセンベイ 7〜 $9 \mathrm{~kg} / \mathrm{cm}^{2}$ で従来の低水分食品 にたいし、破砕強度は低いことを示している。このこと は乾燥製品の輸送中に機械的な衝激、振動、圧力によっ て破損しやすいことを意味し、その結果は外観上の品質 低下の原因となる。ゆえに、包装容器の材質、形状を検 討も包装上の一つの問題点といえよう。

乾燥食品の品質を容器中に打いて安定に保つために は、製品の水分を低水分に保つ必要のあることはすでに のべたが、その程度は水分 $1 \%$ たた法それ以下が望ま乙 い。乾燥機中で水分 $1 \%$ まで乾燥するには非常に長時間 を必要とする。たとえば水分 $3 \%$ の粉末果汁を乾燥機中 で $5 \mathrm{mmHg}$ 以下の真空度で乾燥し、水分 $1 \%$ 粉末果 汁とするには 30〜50 時間を必要とする。このことは乾

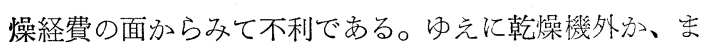
たは、製品容器中で水分調整 (moisture conditioning) を行う必要がある。水分調整を行うに注乾燥剤を充㙗し
た箱、または室、すなわち、低湿度の環境に一定期間放 する。また容器へ充填したまま、すなわち、市販品の状 態で水分調整を行うには、製品を容器へ充填するさい に、生石灰、シリカゲル、活性アルミナなどの乾燥剤を 通気性のある紙袋に入礼、製品と同時に充塡する方法を 採用する (in package desiccation........IPD と略記)。 I P D を行なうさいの乾燥剤の充填量は製品の充填重量 の10\%程度が適当である。いずれの場合もこの処理によ り10〜30日で $1 \%$ 以下の水分に調整することができる。 このような低水分のもの浪食品として苛酷な条件貯蔵 されても、安定な状態に保たれる。

\section{むすび}

以上凍結乾燥食品について筆者の研究結果と欧米の研 究結果をもとに概括的な解説を試夕た。わが国において 凍結乾燥方法による食品は未だ市販の段階には至ってい ない。その大きな理由としては、乾燥装置に相当程度の 経費を必要とすることである。すなわち、この乾燥には 比較的高真空を必要之するため、装置の素材およびその 加工従来の常圧に少ける乾燥装置より経費がかさむこ とから、乾燥製品の販売価格も従来の乾燥食品より高価 にならざるを得ないためと考えてよいであろう。しか し、その製品の品質は従来の乾燥食品にたいする概念を 一新するにたるものであるから、その乾燥経費は品質の 優秀さにより、相殺することが可能であるう。また、近 年のわれわれの生活合理化の傾向は上述のすぐれた品質 の乾燥食品の出現を要求して和り、わが国の真空技術 は懸念される経済的な問題を解消し得る域に達してきて いる。こ机ら二つの理由から近い将来に凍結乾燥方法に よる新しい乾燥食品がわれわ秃の食着をにぎわすように なるものと考えている。

\section{、真 空 4 月号予告}

綜

マイクロバランスの話

実験用ガス液化器について

(下)
説 石 村 志 北川浩 - 石井寿一
究 